\title{
Analisis Perbandingan Prestasi Belajar Mata Kuliah Ilmu Gizi Mahasiswa Kesehatan Berdasarkan Jalur Penerimaan Mahasiswa Baru
}

\author{
Elita Endah Mawarni ${ }^{\text {a }}$ \\ ${ }^{a}$ Prodi S1 Gizi, STIKES Banyuwangi, Banyuwangi,Indonesia \\ Email Korespondensi: litaendah36@gmail.com
}

\begin{abstract}
Introduction: This descriptive study examined (1) to obtained description learning achievement of students received through PMDK and Reguler pathways on Diploma of Nursing and Diploma of Midewifery for Nutrition of Sciences's subject at STIKES Banyuwangi; (2) to determine the differences between learning achievement of students received through PMDK and Reguler pathways on Diploma of Nursing and Diploma of Midewifery at STIKES Banyuwangi. Methode: A documentation technique of 82 students was recruited from diploma of nursing and diploma of midwifery with year entry on 2015 at STIKES Banyuwangi. Result:Descriptive statistics and inferential statistics were utilized to analyse the data. Result of research analysis showed that the learning achievement of Diploma Nursing and Midewifery Department's Students of STIKES Banyuwangi received in year 2015 through PMDK were averagely of 3,00 and dominated by students who have learning achievement with satisfactory category; learning achievement of Diploma Nursing and Midewifery Department's students of STIKES Banyuwangi received through Reguler pathways were averagely 2.89 and dominated by students who have learning achievement with satisfactory categories. Conclusion: The study found that learning achievement throught PMDK Diploma of Nursing and diploma of Midewifery averagely of 3,00 and dominated by satisfactory category; while learning achievement by reguler averagely 2.89 and dominated by satisfactory category; based on the testing of hypothesis, this study there were not differences between learning achievement of students received through PMDK and Reguler pathways on Diploma of Nursing and Diploma of Midewifery for Nutrition of Sciences's subject at STIKES Banyuwangi.
\end{abstract}

Keywords: : learning achievement of students, nutrition of Sciences's, students received

\begin{abstract}
Abstrak
Penduhuluan: Penelitian ini bertujuan untuk (1)Mengetahui gambaran prestasi belajar mata kuliah berbasis gizi pada mahasiswa yang diterima melalui jalur umum dan PMDK pada jurusan D3 Keperawatan dan D3 Kebidanan (2) Mengetahui perbedaan prestasi mata kuliah berbasis gizi pada mahasiswa yang diterima melalui jalur umum dan PMDK pada jurusan D3 Keperawatan dan D3 Kebidanan STIKES Banyuwangi. Metode: Penelitian ini merupakan penelitian diskriptif. Populasi penelitian sekaligus menjadi sampel penelitian sebanyak 82 mahasiswa program studi D3 Keperawatan dan D3 Kebidanan angkatan 2015. Teknik pengambilan data dilakukan dengan menggunakan teknik dokumentasi dan analisis data digunakan statistik diskriptif dan statistik inferensial.Hasil: Hasil penelitian menunjukkan bahwa prestasi belajar mata kuliah berbasis gizi mahasiswa Prodi D3 Kebidanan dan Keperawatan angkatan 2015 yang diterima melaui jalur PMDK secara rata-rata adalah 3,00 dan di dominasi oleh mahasiswa yang memiliki prestasi belajar dengan kategori memuaskan, bahwa prestasi belajar mata kuliah berbasis gizi mahasiswa Prodi D3 Kebidanan dan Keperawatan angkatan 2015 yang diterima melalui jalur Reguler secara rata-rata adalah 2,89 dan di dominasi oleh mahasiswa yang memiliki prestasi belajar dengan kategori memuaskan. Berdasarkan hasil pengujian hipotesis, disimpulkan bahwa tidak ada perbedaan prestasi belajar mata kuliah berbasis gizi mahasiswa jurusan D3 Keperawatan dan D3 Kebidanan STIKES Banyuwangi jika ditinjau berdasarkan jalur masuk Reguler dan PMDK.
\end{abstract}


Kata kunci: jalur penerimaan mahasiswa, mata kuliah berbasis gizi, prestasi belajar

\section{PENDAHULUAN}

Pendidikan nasional merupakan pendidikan yang berlandaskan Pancasila dan UUD 1945. Menurut Undang-Undang RI No 20 Tahun 2003 tentang Sistem Pendidikan Nasional, pendidikan nasional berfungsi mengembangkan kemampuan dan membentuk watak serta peradaban bangsa yang bermartabat dalam rangka mencerdaskan kehidupan bangsa, bertujuan untuk berkembangnya potensi peserta didik agar menjadi manusia yang beriman dan bertaqwa kepada Tuhan Yang Maha Esa, berakhlak mulia, sehat berilmu, cakap, kreatif, mandiri dan menjadi warga negara yang demokratis serta bertanggung jawab (Depdiknas, 2003)

Dalam keseluruhan proses pendidikan di sekolah, kegiatan belajar merupakan kegiatan yang paling pokok. Ini berarti bahwa berhasil tidaknya pencapaian tujuan pendidikan banyak tergantung pada bagaimana proses belajar yang dialami oleh siswa sebagai anak didik (Slameto, 2010)

Salah satu tujuan proses belajar mengajar adalah adanya perubahan tingkah laku baik aspek pengetahuan (kognitif), aspek sikap (afektif), maupun aspek psikomotorik. Salah satu perubahan aspek kognitif mahasiswa dapat dilihat dari Indeks Prestasi (IP) yang diperoleh. IP dijadikan sebagai tolok ukur penguasaan akademik mahasiswa.
Setiap Institusi pendidikan mulai dari pendidikan dasar hingga pendidikan tinggi, menginginkan peserta didik dan lulusannya mampu berprestasi dalam berbagai bidang. Salah satu bidang prestasi yang menjadi perhatian sebagian besar Institusi pendidikan adalah prestasi dalam bidang akademik yang sering pula disebut dengan prestasi belajar

Pencapaian prestasi akademik mahasiswa dipengaruhi oleh faktor intern dan ekstern. Faktor intern berasal dari dalam diri mahasiswa sendiri seperti motivasi belajar, minat, cara belajar, kesehatan, intelegensi, dan bakat. Faktor ekstern berasal dari dukungan orang tua, masyarakat dan lingkungan sekitar, faktor dosen, bahan bacaan, kurikulum, kondisi sarana dan prasarana kampus.

\section{METODE}

\section{Jenis dan Desain Penelitian}

Jenis penelitian ini adalah penelitian ex post facto, dengan model komparatif. Dalam hal ini yang akan dianalisis adalah perbedaanprestasi belajar mata kuliah Gizi dan Diit mahasiswa jurusan Prodi D3 Keperawatan STIKES Banyuwangi yang diterima melalui jalur reguler dan jalur PMDK angkatan 2015. Penelitian ini dilaksanakan di Jurusan Keperawatan Prodi D3 Keperawatan STIKES Banyuwangi semester genap tahun akademik 2015/2016.dan Prodi D3 
Kebidanan semester ganjil tahun akademik 2016/2017.

\section{Variabel Penelitian dan Definisi Operasional}

Penelitian ini menggunakan dua variabel yang terdiri dari variabel bebas yaitu jalur penerimaan mahasiswa dan variabel terikat yaitu prestasi belajar mata kuliah Gizi dan Diet dan mata kuliah KBKR. Untuk menghindari penafsiran yang berbeda maka penulis mendefinisikan variabel yaitu : (1) jalur penerimaan mahasiswa baru adalah proses seleksi calon mahasiswa baru masuk dalam juruan D3 Keperawatan dan Prodi D3 Kebidanan STIKES Banyuwangi yang dikelompokkan menjadi jalur reguler dan PMDK; (2) Prestasi belajar mata kuliah Gizi dan Diet maupun KBKR adalah hasil belajar mata kuliah Gizi dan Diet maupun KBKR yang dicapai mahasiswa selama mengikuti proses perkuliahan selama satu semester tahun akademik 2015/2016 yang dinyatakan dalam nilai mutu berdasarkan peraturan akademik STIKES Banyuwangi adalah $\mathrm{A}, \mathrm{B}+, \mathrm{B}, \mathrm{C}+, \mathrm{C}, \mathrm{D}+, \mathrm{D}$, dan $\mathrm{E}$ atau dalam angka yaitu $4,3.5,3,2.5,2$, $1.5,1$, dan 0

\section{Populasi dan sampel}

Populasi dalam penelitian ini adalah seluruh mahasiswa jurusan Prodi D3 Keperawatan angkatan 2015/2016 dengan jumlah 42 orang dan mahasiswa Prodi D3 Kebidanan angkatan 2014/2015 dengan jumlah 40 orang Tahun Akademik 2015/2016 ( Sumber : Bagian Administrasi Akademik, 2015)

Teknik Pengumpulan Data

Teknik pengumpulan data penelitian ini dilakukan dengan dokumentasi. Dokumentasi yang dimaksud adalah pengambilan data yang diperoleh melalui data sekunder yang telah diarsipkan di Prodi D3 Keperawatan angkatan 2015 dan D3 Kebidanan angkatan 2014 yang terdiri dari masingmasing satu kelas.

Kedua kelompok mahasiswa tersebut akan mengalami proses pembelajaran dan perlakuan yang sama, tidak ada kelas khusus akan tetapi berbaur satu sama lain. Pada proses belajar mengajar mahasiswa yang diterima dari kedua jalur diberikan penilaian yang sama pada saat kuis, UTS, UAS untuk setiap mata kuliah yang diajarkan. Tingkat keberhasilan kedua kelompok mahasiswa tersebut dapat dilihat dari Indeks Prestasi (IP) yang diperoleh mahasiswa pada setiap akhir semester.

\section{Analisis Data}

Data dalam penelitian ini dianalisis secara kuantitatif untuk mendapatkan gambaran prestasi mata kuliah berbasis gizi mahasiswa yang diterima berdasarkan jalur reguler dan PMDK pada jurusan D3 Keperawatan dan D3 Kebidanan STIKES Banyuwangi. Sedangkan analisis statistik inferensial dengan menggunakan uji ManWhitney Test, untuk membuktikan hipotesis "Ada perbedaan prestasi belajar mata kulaih berbasis gizi mahasiswa Prodi D3 Keperawatan dan D3 Kebidanan STIKES Banyuwangi yang diterima melalui jalur Reguler dan PMDK.

\section{HASIL}

\section{Diskripsi Data}

Gambaran prestasi belajarmata kuliah berbasis gizi yang meliputi mata kuliah Gizi dan Diet juga mata kuliah KB dan Kesehatan Reproduksi (KBKR) 
melalui jalur reguler dan PMDK pada Prodi D3 Keperawatan dan D3 Kebidanan dapat dilihat dalam Tabel 1.

Tabel 1. Menunjukkan bahwa prestasi belajar mata kuliah berbasis gizi mahasiswa yang diterima melalui jalur PMDK memperoleh nilai tertinggi 3,50 dari nilai maksimum yang mungkin dicapai adalah 4,00 dan nilai terendah adalah 2,00 dari nilai minimum yang mungkin dicapai

adalah 0 sedangkan nilai rata-rata yang dicapai adalah 3,00 dari jumlah sampel 14 orang mahasiswa denganstandar deviasi sebesar 0,48 .

Tabel 1. Statistik Diskriptif Data Prestasi Belajar mata kuliah mata kuliah berbasis gizi berdasarkan jalur penerimaan

\begin{tabular}{lccccccc}
\hline $\begin{array}{c}\text { Jalur } \\
\text { masuk }\end{array}$ & Mean & $\mathrm{N}$ & Dev & StdMin & Max & $\begin{array}{c}\text { Rang } \\
\mathrm{e}\end{array}$ & $\%$ \\
\hline $\begin{array}{l}\text { Regule } \\
\mathrm{r}\end{array}$ & 2,89 & 68 & 0,43 & 2 & 4 & 2 & 82,9 \\
PMDK & 3 & 14 & 0,48 & 2 & 3,5 & 1,5 & 17,1 \\
& & & & & & & \\
\hline Total & & 82 & & 2 & 4 & 2 & 100 \\
\hline
\end{tabular}

Untuk mahasiswa yang diterima melalui jalur Reguler memperoleh nilai tertinggi 4,00 dari nilai maksimum yang mungkin dicapai adalah 4,00 dan nilai terendah adalah 2 dari nilai minimum yang mungkin dicapai adalah 0 sedangkan nilai rata-rata yang dicapai adalah 2,89 dari jumlah sampel 68 orang mahasiswa dengan standar deviasi sebesar 0,43.

Berdasarkan pengkategorian atau penentuan criteria prestasi akademik digunakan acuan sesuai peraturan akademik STIKES Banyuwangi (2015 : 21) sebagai berikut: (1) $0,00-1,99$ : tidak lulus; (2) 2,00 - 2,50 : cukup, (3) 2,56 3,00 : memuaskan, (4) 3,10-3,50 sangat memuaskan dan (4) 3,56 - 4,00 : dengan pujian, diperoleh gambaran prestasi belajar mata kuliah ilmu gizi mahasiswa berdasarkan jalur penerimaan seperti pada Tabel 2.

Tabel 2. Distribusi Frekuensi dan Kategori Prestasi mata kuliah berbasis gizi berdasarkan Jalur Masuk

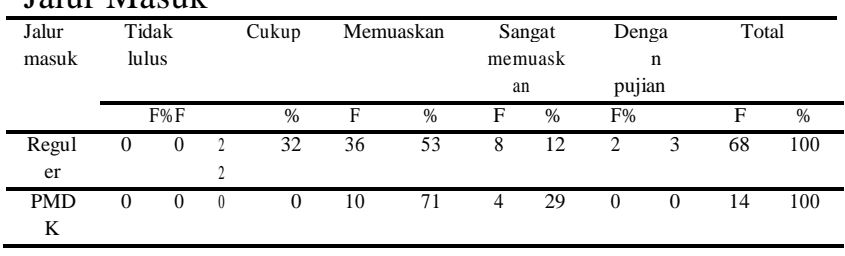

Tabel 2 menunjukkan bahwa dari 68 .mahasiswa yang diterima melalui jalur masuk Reguler terdapat 22 orang atau sebanyak $32 \%$ dinyatakan lulus dengan

nilai cukup, 36 orang atau sebanyak 53\% memiliki prestasi dalam kategori memuaskan, 8 orang atau sebanyak $12 \%$ memiliki prestasi dalam kategori sangat memuaskan dan 2 orang atau sebanyak 3\% memiliki prestasi dengan pujian. Sedangkan mahasiswa yang memiliki prestasi dengan kategori tidak lulus tidak ada. Mahasiswa yang diterima melalui jalur masuk PMDK yang berjumlah 14 orang diperoleh data tidak ada mahasiswa dengan prestasi tidak lulus dan cukup, 10 orang atau sebanyak $71 \%$ memiliki prestasi belajar dalam kategori memuaskan, 4 orang atau sebanyak $29 \%$ memiliki prestasi sangant memuaskan, dan mahasiswa dengan prestasi belajar dalam kategori dengan pujian tidak ada.

\subsection{Pengujian Hipotesis}

Untuk menguji ada tidaknya perbedaan prestasi belajar mata kuliah berbasis gizi berdasarkan jalur penerimaan mahasi swa maka dilakukan analisis statistik inferensial. Berdasarkan variabel bebas yaitu jalur penerimaan mahasiswa dan variabel terikat yaitu prestasi belajar mata kuliah berbasis gizi dimana jumlah 
populasi jalur penerimaan mahasiswa baru adalah proses seleksi calon mahasiswa

baru masuk dalam jurusan D3 Keperawatan dan D3 Kebidanan STIKES Banyuwangi yang dikelompokkan melalui jalur Reguler dan PMDK, terdiri atas 2 jalur maka dipilih analisis uji komparasi "man-whitbey Test"

Dari Tabel 3 output terlihat bahwa hasil statistik hitung berdasarkan uji man whitney test diperoleh perhitungan chisquare adalah 325,5 dengan nilai probabilitas (Asymp, Sig) 0,961

Tabel 3. Pengujian Hipotesis berdasarkan uji man-whitbey test

\section{Mann-Whitney Test}

\begin{tabular}{|l|l|r|r|c|}
\multicolumn{7}{|c|}{ Ranks } \\
& Jalur & N & $\begin{array}{r}\text { Mean } \\
\text { Rank }\end{array}$ & $\begin{array}{c}\text { Sum of } \\
\text { Ranks }\end{array}$ \\
\hline Nilai & reguler & 73 & 41,46 & 3026,50 \\
MAhasi & PMDK & 9 & 41,83 & 376,50 \\
swa & Total & 82 & & \\
\hline
\end{tabular}

\section{Test Statistics ${ }^{\mathrm{a}}$}

\begin{tabular}{|l|r|}
\hline & Nilai MAhasiswa \\
\hline Mann-Whitney U & 325,500 \\
Wilcoxon W & 3026,500 \\
$Z$ &,- 048 \\
Asymp. Sig. (2- &, 961 \\
tailed) & \\
\hline
\end{tabular}

a. Grouping Variable: Jalur MAsuk

\section{Berdasarkan}

pengambilan keputusan menggunakan perbandingan statistik hitung dengan statistik tabel yaitu : jika statistik hitung < statistik tabel, maka Ho diterima dan jika statistik hitung > statistik tabel, maka Ho ditolak.

Hasil pengujian hipotesis menggambarkan bahwa dengan harga chi square atau statistik hitung sebesar 325,5 dengan harga tabel chi square untuk $\mathrm{df}=\mathrm{k}$ -
$1=2-1=1$ dan tingkat signifikan $=0,05$, maka didapatkan nilai statistik tabel $=$ 5,991 dan harga signifikansi (probabilitas sebesar ) 0,961 >0,05.

Berdasarkan dari pengujian, hasil yang diperoleh yaitu Ho diterima dan $\mathrm{Hi}$ ditolak yaitu minimal salah satu dari kedua populasi identik (prestasi belajar mata kuliah berbasis gizi mahasiswa jurusan D3 Keperawatan dan D3 Kebidanan STIKES Banyuwangi yang diterima melalui jalur Reguler dan PMDK tidak berbeda secara signifikan)

\section{PEMBAHASAN}

Berdasarkan analisis diskriptif seperti pada Tabel 1 diperoleh data prestasi belajar mata kuliah berbasis gizi mahasiswa jurusan D3 Keperawatan dan D3 Kebidanan angkatan 2015 berdasarakan jalur masuk mahasiswa yang memiliki ratarata tertinggi adalah yang diterima melalui jalur PMDK sebesar 3, kemudian jalur Reguler sebesar 2,89. Apabila prestasi belajar mahasiswa dianalisis secara sendirisendiri seperti pada tabel 2. Berdasarkan kategori masing-masing jalur masuk diperoleh data untuk mahasiswa yang diterima melalui jalur masuk Reguler terdapat 22 orang atau sebanyak $32 \%$ dinyatakan lulus dengan nilai cukup, 36 orang atau sebanyak $53 \%$

memiliki prestasi dalam kategori memuaskan, 8 orang atau sebanyak $12 \%$ memiliki prestasi dalam kategori sangat memuaskan dan 2 orang atau sebanyak 3\% memiliki prestasi dengan pujian. Mahasiswa yang diterima melalui jalur masuk PMDK yang berjumlah 14 orang diperoleh data, 10 orang atau sebanyak $71 \%$ memiliki prestasi belajar dalam kategori memuaskan, 4 orang atau 
sebanyak $29 \%$ memiliki prestasi sangat memuaskan.

Berdasarkan uraian tersebut diatas menunjukkan bahwa mahasiswa yang diterima melalui jalur PMDK mempunyai rata-rata prestasi belajar lebih tinggi dibandingkan dengan jalur Reguler serta didominasi oleh mahasiswa yang memiliki prestasi belajar pada kategori memuaskan, mahasiswa yang diterima melalui jalur masuk Reguler didominasi oleh mahasiswa yang memiliki prestasi belajar pada kategori memuaskan. Hal tersebut dapat disimpulkan bahwa tidak terdapat perbedaan prestasi belajar mata kuliah berbasis gizi mahasiswa jurusan D3 Keperawatan dan D3 Kebidanan STIKES Banyuwangi yang diterima melalui jalur Reguler dan PMDK .

Kesimpulan diatas didukung
dengan hasil pengujian hipotesis
menggambarkan bahwa dengan harga chi square atau statistik hitung sebesar 325,5 dengan harga tabel chi square untuk $\mathrm{df}=\mathrm{k}$ $1=2-1 \quad=1$ dan tingkat signifikansi (probabilitas sebesar) 0,961 lebih besar dari 0,005. Dengan demikian dapat diketahui bahwa tidak ada perbedaan prestasi belajar mata kuliah berbasis gizi mahasiswa jurusan D3 Keperawatan dan D3 Kebidanan STIKES Banyuwangi jika ditinjau berdasarkan jalur masuk Reguler dan PMDK .

Prestasi belajar mata kuliah berbasis gizi mahasiswa jurusan D3 Keperawatan dan D3 Kebidanan angkatan 2015 yang diterima melalui jalur PMDK ini seharusnya lebih tinggi dari pada prestasi mahasiswa reguler hal ini bisa dipahami karena mahasiswa yang lolos seleksi melalui jalur PMDK, penerimaan berdasarkan nilai rapor sekolah tanpa melalui tes masuk dan lebih mengutamakan pada siswa yang memiliki prestasi di masing-masing sekolah serta mempertimbangkan tingkat intelegensia, sehingga tingkat intelegensia dapat berpengaruh terhadap prestasi belajar. Namun dari hasil penelitian ini prestasi mahasiswa PMDK dan Reguler sama, hal ini bisa diasumsikan bahwa keberhasilan seseorang dalam mencapai prestasi khususnya bidang pendidikan , baik formal maupun non formal salah satunya dipengaruhi oleh faktor eksternal yaitu faktor lingkungan kampus. Menurut Sampoerno, 2002, pengaruh lingkungan kampus terhadap prestasi dapat dilihat dari adanya interaksi antara mahasiswa dengan dosen dan persepsi mahasiswa terhadap lingkungan almamaternya. Persepsi mahasiswa terhadap dosen dan lingkungan almamater juga dapat mempengaruhi motivasi belajar mahasiswa.

Prestasi belajar mata kuliah berbasis gizi mahasiswa jurusan D3 Keperawatan dan D3 Kebidanan angkatan 2015 yang diterima melalui jalur Reguler lebih rendah dari jalur PMDK dan didominasi prestasi belajar pada kategori memuaskan. Hal ini disebabkan karena pola seleksi yang bersifat lokal yang mengakibatkan persaingan kurang ketat dan mahasiswa yang diterima pada jalur ini adalah mereka yang kebanyakan tidak lolos melalui jalur PMDK yang dilaksanakan lebih awal.

\section{KESIMPULAN DAN SARAN}

\section{Kesimpulan}

Dari hasil penelitian dapat disimpulkan beberapa hal yaitu :

1. Prestasi belajar mata kuliah berbasis gizi mahasiswa jurusan $\mathrm{D} 3$ 
PROFESIONAL HEALTH JOURNAL

Volume 1, No. 1, Desember 2019 (Hal. 1-8)

Available Online at https:// http://ojsstikesbanyuwangi.com

Keperawatan dan D3 Kebidanan angkatan 2015 yang diterima melalui jalur PMDK dengan ratarata 3 dan didominasi mahasiswa yang memiliki prestasi memuaskan, Prestasi belajar mata kuliah berbasis gizi mahasiswa jurusan D3 Keperawatan dan D3 Kebidanan angkatan 2015 yang diterima melalui jalur Reguler dengan ratarata 2,89 dan didominasi mahasiswa yang memiliki prestasi memuaskan.

2. Tidak terdapat perbedaan prestasi belajar mata kuliah berbasis gizi mahasiswa jurusan D3 Keperawatan dan D3 Kebidanan STIKES Banyuwangi yang diterima melalui jalur Reguler dan PMDK .

\section{Saran}

1. Bagi Responden

Kemauan belajar merupakan salah satu modal utama untuk meraih sukses, untuk itumanfaatkanberbagaimedia

pembelajaran yang tersedia luas. Manfaatkan fasilitas pembelajaran yang ada yang bersifat interaktif untuk melatih berfikir kritis serta berusaha untuk dapat mengenali lingkungan kampus.

2. Bagi Dosen

Tingkatkan kompetensi dosen dengan meningkatkan update pengetahuan melalui studi lanjut, melaksanakan penelitian, menulis buku ajar. Terapkan berbagai macam strategi pembelajaran yang sesuai dengan tema dan usahakan untuk terjadinya proses interaktif antara mahasiswa dengan mahasiswa dan dosen. Terapkan system pembelajaran yang mampu memicu keaktifan mahasiswa, karena kondisi tersebut mampu memicu semangat mahasiswa dan menghilangkan kejenuhan dan kebosanan

3. Bagi Institusi pendidikan

Fasilitas yang ada mohon untuk dioptimalisasikan fungsinya, termasuk fasilitas untuk Wifi, mohon kiranya untuk di updae, karena dapat mempengaruhi akses mahasiswa terhadap materi-materi yang bersifat interaktif.

\section{DAFTAR PUSTAKA}

Arikunto, Suharsimi.2003..Dasar-dasar EvaluasiPendidikan.Jakarta: BumiAksara

Departemen Pendidikan Nasional (2008). Kamus Besar Bahasa Indonesia. Jakarta: PT Gramedia Pustaka Utama

Sampoerno, P.D., 2002, Analisis Kualitas Mahasiswa dalam Pencapaian Pendidikan dengan Menggunakan Partial Least Square, Tesis, Program Pascasarja Institut Pertanian Bogor

Slameto. (2010). Belajar dan Faktor-faktor yang Mempengaruhinya. Jakarta: Rineka Cipta

Suherman, 2013. Studi Tentang Pencapaian Hasil Belajar Mahasiswa Jurusan Matematika FMIPA UNP Menurut Jalur Masuk.http://jurnal.fmipa.unila.ac.id/ index.php/semirata/articcle/downloa d/925/744. Di akses pada tanggal 2 Desember 2016

\footnotetext{
Usman.2015. Analisis Perbandingan Prestasi Belajar Fisika Dasar Mahasiswa Berdasarkan Jalur Penerimaan Mahasiswa Baru di Jurusan Fisika Fakultas Matematika
} 
PROFESIONAL HEALTH JOURNAL

Volume 1, No. 1, Desember 2019 (Hal. 1-8)

Available Online at https:// http://ojsstikesbanyuwangi.com

dan Ilmu Pengetahuan Alam

Universitas Negeri Makassar. Jurnal

Sains dan Pendidikan Fisika Jilid 11,

Nomor 1, April 2015, Hlm : 40-4 
PROFESIONAL HEALTH JOURNAL

Volume 1, No. 1, Desember 2019 (Hal. 1-8) Available Online at https:// http://ojsstikesbanyuwangi.com 